\title{
Parasites of Percophis brasiliensis (Percophidae) benefited from fishery regulations: Indicators of success for marine protected areas?
}

\author{
Paola E. Braicovich ${ }^{1}$ \\ Manuel M. Irigoitia ${ }^{1}$ \\ Nelson D. Bovcon ${ }^{2}$ \\ Juan T. Timi ${ }^{1}$ @
}

${ }^{1}$ Laboratorio de Ictioparasitología, Instituto de Investigaciones Marinas y Costeras, Facultad de Ciencias Exactas y Naturales, Universidad Nacional de Mar del Plata- Consejo Nacional de Investigaciones Científicas y Técnicas, Mar del Plata, Argentina

${ }^{2}$ Laboratorio de Investigación en Hidrobiología, Facultad de Ciencias Naturales y Ciencias de la Salud, Universidad Nacional de la Patagonia San Juan Bosco, Trelew, Chubut, Argentina

\section{Correspondence}

Paola E. Braicovich, Laboratorio de Ictioparasitología, Instituto de Investigaciones Marinas y Costeras, Facultad de Ciencias

Exactas y Naturales, Universidad Nacional de Mar del Plata - Consejo Nacional de Investigaciones Científicas y Técnicas, Funes 3350, (7600) Mar del Plata, Argentina.

Email: braicovi@mdp.edu.ar

Funding information

Consejo Nacional de Investigaciones Científicas y Técnicas, Grant/Award Number: 112-201501-00973; Fondo para la Investigación Científica y Tecnológica, Grant/ Award Number: 2018-01981; Universidad Nacional de Mar del Plata, Grant/Award Number: 1016/20

\section{Abstract}

1. Fishing is the greatest source of anthropogenic impact on global marine resources and the ecosystems supporting them. The decline of many fish stocks has led to the need to apply control and protection measures to promote the recovery of these resources.

2. In the Argentine Sea, a multispecies coastal fishery in the El Rincón region has displayed signs of overexploitation since the beginning of the century. Consequently, temporal and spatial protection measures were implemented in 2004.

3. In previous studies, an independent stock of Percophis brasiliensis in El Rincón was identified based on the parasite communities of fish caught in 2005. However, no subsequent studies using parasite communities have been performed since the protective fishery closure measures were applied.

4. To evaluate parasites as indicators of temporal change in the El Rincón stock of $P$. brasiliensis after the implementation of these protection measures, a sample from 2018 was compared with that from the previous study, as well as with three other samples. Two of the latter (Argentine Common Fishing Zone and San Matías Gulf) corresponded to previously identified independent stocks in the Argentine biogeographical province and the third was a new sample from the Magellanic Province in southern Patagonian waters.

5. The structure and composition of parasite assemblages of the El Rincón stock of P. brasiliensis differed significantly in 2018, after several years of protective measures. The increased loads observed in several parasite species constitute a promising signal of successful ecosystem recovery. A discrete stock in the Magellanic Province was also identified, providing insights into the population structure of $P$. brasiliensis along its distributional range, with applications for the sustainable management of this resource.

\section{KEYWORDS}

biological indicators, fisheries, parasite assemblages, Percophis brasiliensis, protection measures 


\section{1 | INTRODUCTION}

Fisheries comprise the greatest anthropogenic impact on global marine resources (Watson et al., 2013). The 20th century saw the decline of many fish stocks (van Gemert \& Andersen, 2018), threatened by continuous depletion of populations and an increasing risk of species extinction, ecosystem regime shifts and even the loss of the overall integrity of marine ecosystems (Mullon, Fréon, \& Cury, 2005; Pauly, Christensen, Dalsgaard, Froese, \& Torres, 1998; Pikitch, 2012). A battery of measurements have been applied worldwide in an attempt to counteract these effects and promote the recovery of the resources, namely harvest regulations, changes in gear selectivity and implementation of spatial and temporal closures at different scales or the creation of marine reserves (de Bruyn, Murua, \& Aranda, 2013; Edgar et al., 2014; Roberts, Hawkins, \& Gelly, 2005; van Gemert \& Andersen, 2018). Although the benefits of these alternatives are highly heterogeneous (Costello et al., 2016), increases in spawning stocks of exploited species are the most frequently reported effects of reserves being fully or partially closed to fishing (Gell \& Roberts, 2002), resulting in the increased abundance, average size and biomass of protected animals, as well as increased diversity (Halpern, 2003).

Fisheries affect not only targeted stocks, but also entire communities of organisms. This includes fish parasites, which are impacted by reduced host abundance and food web complexity, which affect their transmission efficiency, population density and assemblage species richness (Wood \& Lafferty, 2015). Understanding how parasite assemblages respond to protection measures may therefore help to evaluate the degree of effectiveness of fisheries management measures (Isbert et al., 2018).

The coastal region of the Argentine Sea, El Rincón $\left(38^{\circ} 30^{\prime}-41^{\circ}\right.$ $30^{\prime} \mathrm{S}$ ), is a semi-enclosed area that generates its own oceanographic features, where locally modified waters create frontal zones with important biological properties (Acha, Mianzán, Guerrero, Favero, \& Bava, 2004), providing breeding grounds and zones of concentration for juveniles of several fish species by promoting the retention of larvae (Acha, Orduna, Rodrigues, Militelli, \& Braverman, 2012; Carozza et al., 2004). Coastal fisheries had developed and increased markedly in this region, showing signs of overexploitation by the end of the last century (Ruarte, Rico, \& Lagos, 2017). Consequently, as of 2004, an area of this region was closed during the reproductive season of most economically relevant fish species (October to February) as a protection measure. Restrictions were later progressively extended on both temporal and spatial scales, reaching a maximum in 2010, which resulted in decreased landings in subsequent years (Fernández Aráoz, Lagos, \& Carozza, 2014). Several species in the area showed a recovery of biomass between 2009 and 2012 (Ruarte et al., 2017), but no further evaluation has been carried out, although more than a decade has passed since the implementation of the restrictions.

The Brazilian flathead, Percophis brasiliensis, is one of the main resources in the multispecies demersal fishery operating in the northern Argentine Sea, including the region of El Rincón, where there is an independent stock of this species (Rico, Lagos, Rodríguez, \&
Lorenzo, 2018). The El Rincón stock has been distinguished based on population parameters, otolith microchemistry and parasites (Avigliano, Sáez, Rico, \& Volpedo, 2015; Braicovich \& Timi, 2008; Rico et al., 2018; Rodrígues, Rico, Militelli, Osovnikar, \& Maggioni, 2010). The study of parasites as markers for host population discrimination by Braicovich and Timi (2008) was conducted on flatheads caught in El Rincón in 2005, shortly after the application of fishing restrictions. A recovery in the biomass of several fish species, including $P$. brasiliensis, was recorded after the implementation of protection measurements, with data recorded until 2012 (Ruarte et al., 2017). The present parasite assemblages of flatheads from El Rincón could shed additional light on the the effectiveness of the management measures applied. To that end, the present study includes a comparison of parasites from $P$. brasiliensis caught at El Rincón in 2018 with those caught in 2005, as well as with neighbouring stocks in the Argentine Common Fishing Zone and in San Matías Gulf (Braicovich \& Timi, 2008).

In the Argentine Sea, all studies on the population structure of $P$. brasiliensis were carried out in waters off Buenos Aires Province and San Matías Gulf (Rico et al., 2018). The first region belongs to the Argentine biogeographical province, and the second has been assigned to the Argentine or the Magellanic Province (Balech \& Ehrlich, 2008; Menni, Jaureguizar, Stehmann, \& Lucifora, 2010; Miloslavich et al., 2011), constituting an ecotonal region. However, P. brasiliensis has a broader distribution, reaching the San Jorge Gulf in Patagonian waters $\left(47^{\circ} \mathrm{S}\right.$; Cousseau \& Perrotta, 2013), which has characteristics typical of the Magellanic Province. In waters off Buenos Aires province, this species performs seasonal latitudial and bathymetric migrations (Barretto, Sáez, Rico, \& Jaureguizar, 2011); however, there is no information on the stock composition in southern Patagonian waters or the possible migration from lower latitudes towards that region.

Fish inhabiting the Magellanic Province harbour parasite assemblages characteristic of that region, which are different enough from those in the Argentine Province to successfully discriminate stocks of several fish species (Cantatore \& Timi, 2015; Lanfranchi et al., 2016, 2018). Consequently, it is likely that at least one different stock of $P$. brasiliensis exists in Patagonian waters. In the present paper, samples caught in the Magellanic region were included in comparisons to analyse for the first time the population structure of this species in that region. The aim of this work was, therefore, two-fold: (1) to evaluate how parasite communities of $P$. brasiliensis changed in response to measures promoting the recovery of the resource; and (2) to test the hypothesis that a different stock of $P$. brasiliensis exists in Magellanic waters.

\section{2 | METHODS}

Seventy-five specimens of $P$. brasiliensis, distributed in three samples from two localities in the Argentine Sea, belonging to two biogeographical provinces, were examined for metazoan parasites (Figure 1, Table 1). Fish were obtained from research cruises and commercial catches and deep-frozen in individual plastic bags at $-18^{\circ} \mathrm{C}$ until 
FIGURE 1 Map showing sampling sites and zoogeographical provinces. MDP, Mar del Plata; ER1, El Rincón 2005; ER2, El Rincón 2018; SMG, San Matías Gulf; RA1, Rawson 2016; RA2, Rawson 2017; striped region, protected area

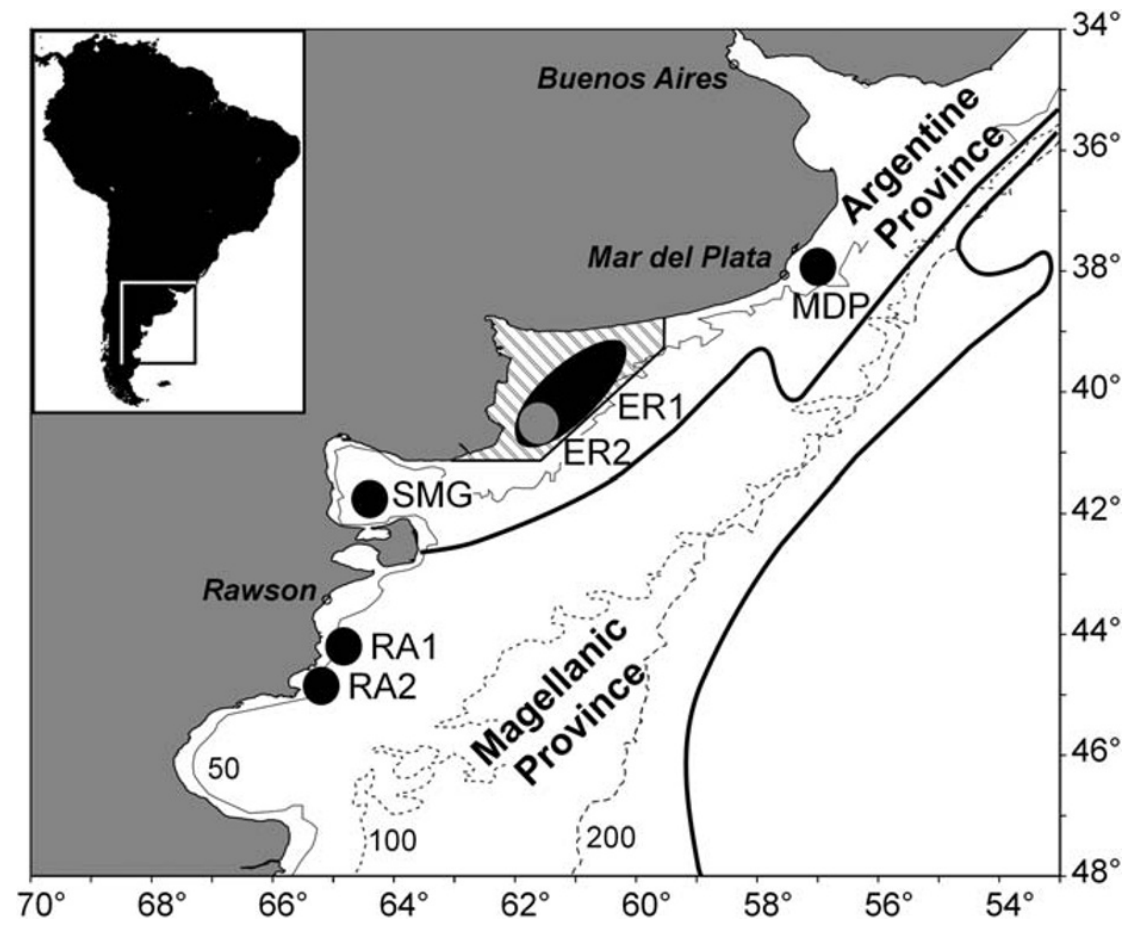

TA B LE 1 Composition of samples of Percophis brasiliensis in six localities of the Argentine Sea (ordered by latitude)

\begin{tabular}{|c|c|c|c|c|c|c|c|}
\hline Sample & $\begin{array}{l}\text { Sample } \\
\text { code }\end{array}$ & $N$ & Latitude/longitude & Date & $\begin{array}{l}\text { Total length } \pm S D \\
\text { (range) }(\mathrm{cm})\end{array}$ & $\begin{array}{l}\text { Biogeographical } \\
\text { province }\end{array}$ & Source \\
\hline $\begin{array}{c}\text { Mar del } \\
\text { Plata }\end{array}$ & MDP & 51 & $38^{\circ} \mathrm{S} ; 57^{\circ} \mathrm{W}$ & $10 / 2005$ & $56.4 \pm 6.5(44.0-71.0)$ & Argentine & $\begin{array}{r}\text { Braicovich \& } \\
\text { Timi, } 2010\end{array}$ \\
\hline $\begin{array}{l}\text { El Rincón } \\
2005\end{array}$ & ER1 & 51 & $\begin{array}{l}39-41^{\circ} \mathrm{S} ; 60-62^{\circ} \\
\mathrm{W}\end{array}$ & $10 / 2005$ & $50.0 \pm 3.7(45.0-58.0)$ & Argentine & $\begin{array}{r}\text { Braicovich \& } \\
\text { Timi, } 2008\end{array}$ \\
\hline $\begin{array}{l}\text { El Rincón } \\
2018\end{array}$ & ER2 & 40 & $\begin{array}{l}40^{\circ} 57^{\prime} \mathrm{S} ; 61^{\circ} 37^{\prime} \\
\mathrm{W}\end{array}$ & $10 / 2018$ & $49.2 \pm 3.3(43.8-58.0)$ & Argentine & Present study \\
\hline $\begin{array}{l}\text { San Matías } \\
\text { Gulf }\end{array}$ & SMG & 32 & $\begin{array}{l}41^{\circ} 40^{\prime}-42^{\circ} 10^{\prime} \mathrm{S} \\
63^{\circ} 50^{\prime}-65^{\circ} 00^{\prime} \mathrm{W}\end{array}$ & $01 / 2006$ & $52.9 \pm 6.7(41.0-66.0)$ & Ecotone & $\begin{array}{r}\text { Braicovich \& } \\
\text { Timi, } 2008\end{array}$ \\
\hline $\begin{array}{c}\text { Rawson } \\
2016\end{array}$ & RA1 & 23 & $\begin{array}{l}43^{\circ} 47^{\prime} \mathrm{S} ; 65^{\circ} 00^{\prime} \\
\quad \mathrm{W}\end{array}$ & $10 / 2016$ & $54.7 \pm 3.3(48.5-62.0)$ & Magellanic & Present study \\
\hline $\begin{array}{c}\text { Rawson } \\
2017\end{array}$ & RA2 & 12 & $\begin{array}{l}43^{\circ} 52^{\prime} \mathrm{S} ; 65^{\circ} 30^{\prime} \\
\quad \mathrm{W}\end{array}$ & $03-04 / 2017$ & $55.9 \pm 5.8(45.0-63.5)$ & Magellanic & Present study \\
\hline
\end{tabular}

Note: $\mathrm{N}$, number of fish examined.

examination. After thawing, the total length was measured (TL, $\mathrm{cm})$ and each fish was processed as in Braicovich and Timi (2008, 2010).

In order to evaluate possible changes in parasite populations after the implementation of protection measures in El Rincón (ER), previously published data for 51 flatheads caught in 2005 (Braicovich \& Timi, 2008) were included. Additionally, to reveal recurrent distributional patterns, two samples from neighbouring localities were included in the analyses for comparative purposes: one from Mar del Plata coast and one from San Matías Gulf, captured in 2005-2006 (Braicovich \& Timi, 2008, 2010). The datasets, totalling 209 examined fish, are summarized in Table 1.

The total length of fish was compared across samples by a one-way permutational multivariate analysis of variance (PERMANOVA;
Anderson, Gorley, \& Clarke, 2008) on the Euclidean distances $(1 \times 6$ factorial design, 'sample' as a fixed factor), testing for main effects after 9,999 permutations and subsequent post-hoc pairwise comparisons. Following Anderson et al. (2008), an unrestricted permutation of raw data was used.

Prevalence and mean abundance for each parasite species in each locality were calculated following Bush, Lafferty, Lotz, and Shostak (1997); long-lived larval parasites were selected for all subsequent analyses since these parasite species are persistent for long periods or even for the entire life of hosts, and therefore are more reliable for comparisons (Braicovich, Pantoja, Pereira, Luque, \& Timi, 2017). Indeed, as long-lived parasites live in the body cavity or encysted in tissues, no seasonal variability in the parasite loads is 
expected for these larvae; therefore, their burdens and community structure remain stable throughour host migratory routes (Timi \& MacKenzie, 2015).

Owing to the large differences in parasite abundance across parasite species, data were square-root transformed prior to multivariate analyses to down-weight the importance of very abundant species, such that less dominant species also played a role in determining similarity among samples (Clarke \& Gorley, 2015). A Bray-Curtis similarity matrix was computed at infra-community level (sensu Bush et al., 1997) for the long-lived parasite assemblages and was subjected to multivariate analyses.

In order to visualize possible temporal and geographic patterns in the composition of parasite assemblages across the samples, non-metric multidimensional scaling (nMDS) of the similarity matrix was performed between all infra-communities and their centroid differences were visualized by means of bootstrap averaging based on repeated resampling (with replacement, 90 iterations) from the original dataset (Clarke \& Gorley, 2015). Average values were then visualized in an nMDS using as many dimensions as needed to closely match the original distance matrix (correlation coefficient of $\rho=0.99$ ) and the fit of the nMDS ordinations was quantified by a stress value.

Differences between infra-communities among samples were examined in more detail using canonical analysis of principal coordinates (CAP) (Anderson et al., 2008; Anderson \& Willis, 2003) on the same similarity matrix. The potential for over-parameterization was prevented by choosing the number of PCO axes $(m)$ that maximized a leave-one-out allocation success to groups (Anderson \& Robinson, 2003). To test for differences between infra-communities among the samples, a permutation 'trace' test (sum of squared canonical eigenvalues) was applied and a $P$-value was obtained after 9,999 permutations.

Since MDS and CAP analyses do not take into account possible biases introduced by differences in host size, the structure of long-lived parasite infra-communities was compared between samples $(1 \times 6$ factorial design, samples as fixed factors) by means of a one-way permutational multivariate analysis of variance (PERMANOVA), with host size as a covariable and testing for main effects after 9,999 permutations and subsequent post-hoc pair-wise comparisons. Following Anderson et al. (2008), a permutation of residuals with a reduced model was used as the method of permutation. A sequential sum of squares (type I) was applied because host size was introduced as a covariable (ANCOVA model).

For those species with prevalence $>10 \%$, in at least one of the samples (component species; Bush, Aho, \& Kennedy, 1990), $\chi^{2}$ analysis was used to test for significant differences in prevalence between samples from ER captured in different years (Zar, 1999). General linear models were applied to test differences in the abundance of parasites (response variable) owing to the capture year and the total length of host (explanatory variables). Terranova sp. and Pseudoterranova cattani were excluded from the analysis because they were absent in one of the two samples. In these comparative analyses, an adult parasite, Moravecia argentinensis, was included because it inhabits the blood vessels and is the unique strictly specific parasite of
P. brasilianus with prevalence $>10 \%$. A negative binomial error distribution was used owing to the discrete nature of the data (counts) (Zuur, leno, Walker, Saveliev, \& Smith, 2009), employing the MASS package (Ripley et al., 2019). The significance of each explanatory variable on the models produced was assessed through Anova tables for Various Statistical Models employing a $\chi^{2}$ test, in CAR package (Fox et al., 2016). The analyses were performed in $\mathrm{R}$ software version 3.6.1 (r-project.org).

Finally, a nMDS was performed using the Bray-Curtis similarity index on prevalence data to visualize possible geographic patterns in the composition of parasite assemblages across the six samples at the component community level (sensu Bush et al., 1997). Hierarchical agglomerative clustering was applied to the component communities using group-average linking, and resemblance levels were overlaid on the nMDS plot (Clarke \& Gorley, 2015).

\section{3 | RESULTS}

Twenty-four parasite taxa were found in samples of $P$. brasiliensis (Table 2), 13 of which were long-lived larval stages that accounted for 92.4\% of parasites found. Larval stages of nematodes Pseudoterranova cattani and Hysterothylacium aduncum were recorded for the first time in this host, in samples from ER2 and RA.

Significant differences in fish length across samples (Table 3) were due to the smaller flatheads from ER1 and ER2 relative to all other samples (all $P_{\text {perm }}<0.01$ ). Fish from ER1 and ER2 did not differ in size $\left(P_{\text {perm }}>0.01\right)$, nor were there differences in size among fish from the remaining samples (all $P_{\text {perm }}>0.01$ ).

The bootstrap-average-based nMDS ordination of long-lived parasites (Figure 2) showed a pattern of separation between infra-communities from different samples, with a low level of stress (0.08). Indeed, the parasite assemblages from the four sites were mostly distributed along the first axis with both samples from ER being situated apart from each other, while those from RA constituted a rather homogeneous group.

A similar pattern of samples discrimination was revealed by the CAP analysis (Figure 3a), which showed significant differences amongst the samples $(t r=2.20, P<0.01$ ). The selected orthonormal principal coordinates (PCO) axes $(m=7)$ described $98.3 \%$ of the variation in the data cloud, with $82.8 \%$ correct allocations of infracommunities into the pre-established groups, and a misclassification error of $17.2 \%$. Cross-validation of the results (Table 4) showed that higher percentages of correctly allocated infra-communities occurred in MDP and ER2, whereas those from RA2 showed lower proportions of correct allocations, owing mainly to misclassification of RA2 hosts in RA1. Indeed, the two first canonical axes resulting from the CAP separated the samples mainly along the first axis and a strong association between the multivariate data 'cloud' and the hypothesis of group differences as indicated by the reasonably large size of their canonical correlations $\left(d_{1}=0.94\right.$ and $\left.d_{2}=0.76\right)$. In that sense, both samples from the Magellanic Province (RA1 and RA2) were located at the left of the biplot, being characterized by the abundances of 


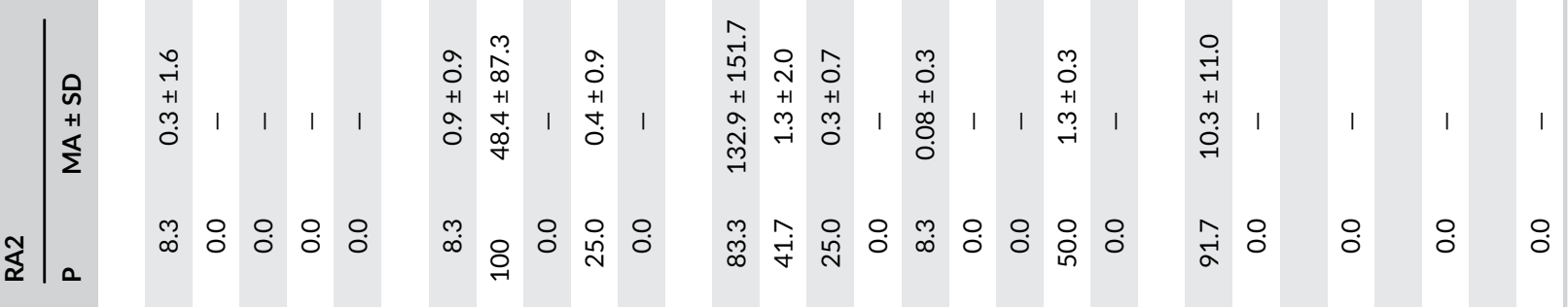

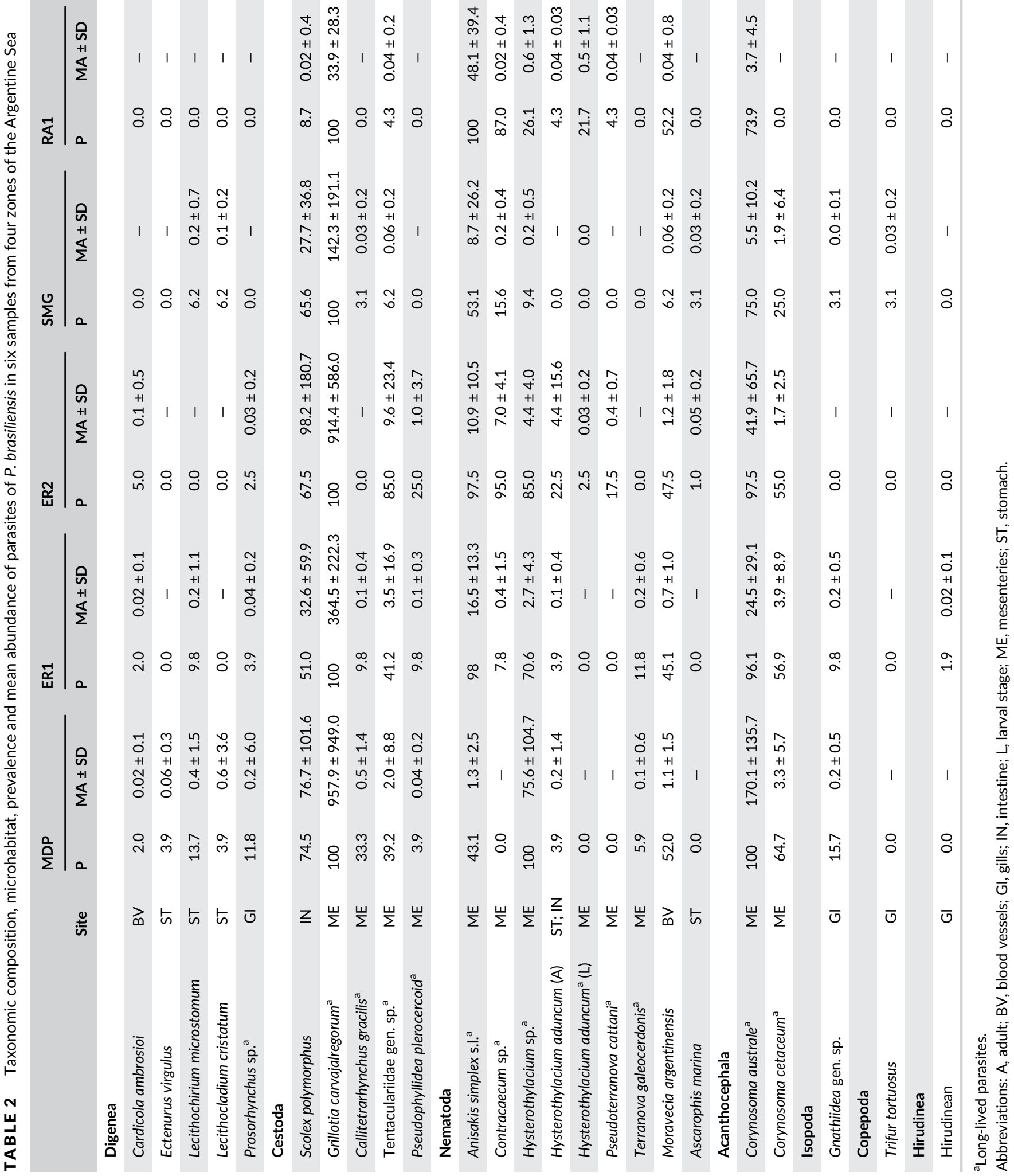


TAB LE 3 PERMANOVA results of comparisons of host total length and infra-community structure of long-lived parasites of $P$. brasiliensis across six samples from four zones of the Argentine Sea

\begin{tabular}{|c|c|c|c|c|c|c|}
\hline Response variable & Source & d.f. & SS & MS & Pseudo F & $P($ perm $)$ \\
\hline Fish total length & Sample & 5 & $1,900.4$ & 380.07 & 14.564 & 0.0001 \\
\hline Euclidean distance & Residual & 203 & $5,297.6$ & 26.096 & & \\
\hline Infracommunity structure & Host size & 1 & 3,311.4 & $3,311.4$ & 6.7381 & 0.0028 \\
\hline \multirow[t]{3}{*}{ Bray-Curtis similarity } & Sample & 5 & $1.4251 e^{05}$ & 28,502 & 57.997 & 0.0001 \\
\hline & Residual & 197 & 96,814 & 491.44 & & \\
\hline & Total & 208 & $2.723 e^{05}$ & & & \\
\hline
\end{tabular}

Note: $P$-values obtained after 9,999 permutations.

Abbreviations: d.f., degrees of freedom; MS, mean squares; SS, sum of square.

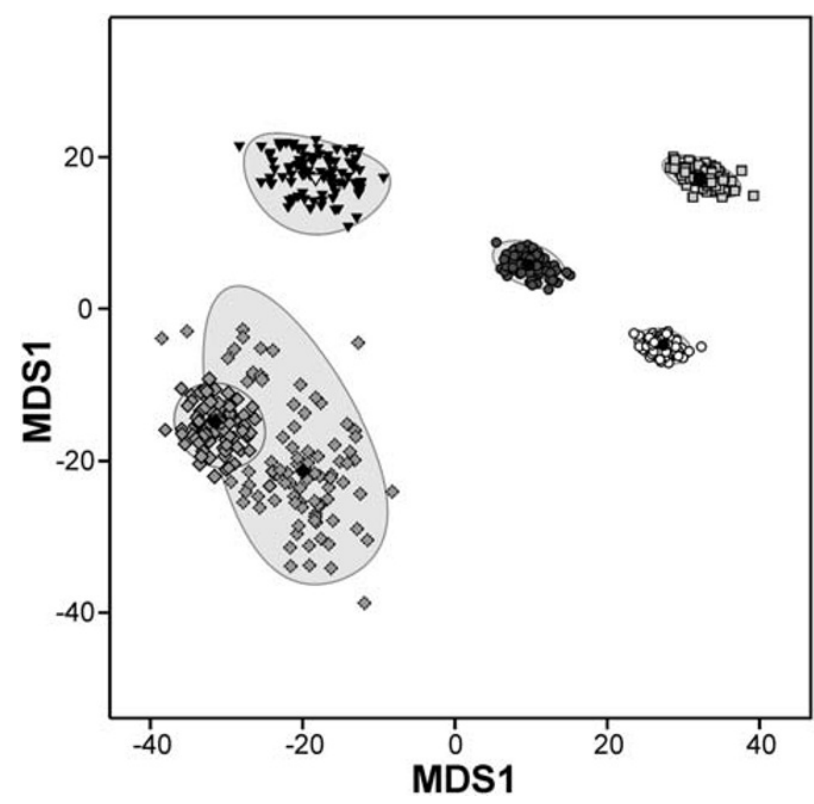

FIGURE 2 Non-metric multi-dimensional scaling plot of bootstrap averages (90 repetitions) of parasite infra-communities in six samples of long-lived parasites of Percophis brasiliensis from the south-western Atlantic based on Bray-Curtis dissimilarity of square root-transformed data. Individual repetitions are based on random draw and replacement of samples from the original dataset. Black symbols and white triangle represent the overall centroids across all repetitions. Grey areas represent 95\% confidence regions. Squares, Mar del Plata; grey circles, El Rincón 1; white circles, El Rincón 2; solid border rhombuses, Rawson 1; dotted border rhombuses, Rawson 2; triangles, San Matías Gulf

Anisakis simplex s.l. (Figures 3a,b) and Contracaecum sp. (Figures 3a,c), whereas those from the Argentine Province were at the right and related to a group of indicator species composed mainly of the larval acanthocephalan Corynosoma australe (Figures 3a,d), the cestode Grillotia carvajalregorum (Figures 3a,e) and the nematode Hysterothylacium sp. (Figures 3a,f), the latter species mostly associated with flatheads caught at ER in 2018.

The resemblance of long-lived parasite infra-communities was influenced by host size, which also interacted with sample origin
(Table 3). However, the sample also had a significant effect independent of this, and pair-wise tests between host samples after accounting for host size showed differences between most pairs $\left(P_{\text {(perm) }}<0.01\right)$, with the exception of those from RA1 and RA2 $\left(P_{(\text {perm })}>0.01\right)$. Differences in the multivariate dispersions can be partially responsible for such a lack of pattern since PERMDISP results were highly significant $\left(F_{5,203}=16.842 P_{\text {(permdisp) }}<0.01\right)$, owing to comparisons involving samples from ER1 and RA2 (all $P_{\text {(perm) }}<0.01$ ).

Comparisons of parasite prevalence between both samples from ER showed that Contracaecum sp., $P$. cattani and Tentaculariidae gen. sp. differed significantly (all $P<0.01$ ), with higher prevalence in samples captured from ER in 2018, compared with those from 2005. The general linear model analyses showed that the year of capture was important in explaining the abundance for most parasite species compared (Table 5), while host size partially explained the variation in abundances for C. australe, G. carvajarlregorum, Hysterothylacium sp. and A. simplex s.l. No significant interaction between capture year and host size was observed for any species. For all those species differing in parasite abundance, the values were higher in fish captured in 2018. For the rest of the species, including Moravecia argentinensis, no significant differences were found (all $P>0.01$ ).

At the level of component communities, the nMDS and cluster analyses carried out for abundances showed a similar pattern to that for infra-communities (Figure 4). Indeed, two groups were clearly separated, one composed of the samples caught in the Argentine Province (MDP, ER1 and ER2) and the other by samples from the Magellanic Province (SMG, RA1 and RA2) with high similarity (65\%).

\section{4 | DISCUSSION}

The parasite fauna of $P$. brasiliensis is probably one of the best known in the south-western Atlantic (Braicovich et al., 2017; Braicovich \& Timi, 2008, 2010). In new samples collected 13 years after prior work, and from the southern distribution area, two new parasites were recorded, yielding a total of 38 species of parasites known for this host.

Marine reserves aim to restore balanced ecosystems to protect resources and habitats (Wootton et al., 2012). After implementing 
FIGURE 3 (a) Canonical analysis of principal co-ordinates (CAP) bi-plot based on Bray-Curtis dissimilarities on square-root abundance data of long-lived parasites of $P$. brasiliensis in six samples in the south-western Atlantic. Vectors represent Pearson's correlations $(r>0.4)$ of the abundance of individual parasite species with the CAP axes. Squares, Mar del Plata; grey circles, El Rincón 1; white circles, El Rincón 2; solid border rhombuses, Rawson 1; dotted border rhombuses, Rawson 2; triangles, San Matías Gulf. AS, Anisakis simplex s.l.; CA, Corynosoma australe; CC, Corynosoma cetaceum; CO, Contracaecum sp.; GC, Grillotia carvajalregorum; HY, Hysterothylacium sp. (b-f) Circle diameters scaled according to the square-rooted abundance for the five main indicator species for stock discrimination in each individual fish. (b) A. simplex s.l.; (c) Contacaecum sp.; (d) C. australe; (e) G. carvajalregorum; (f) Hysterothylacium sp. Circle colours as for (a)

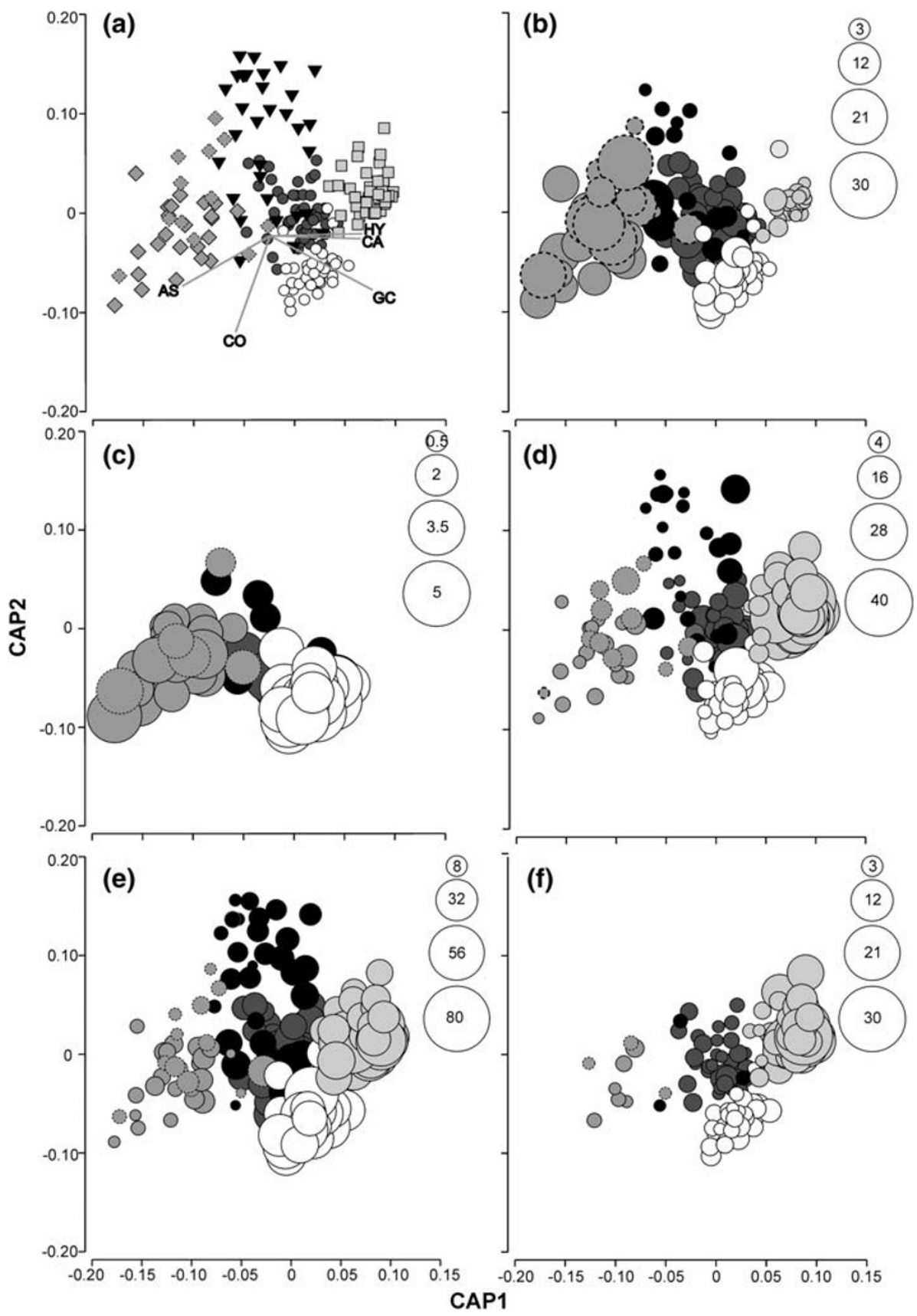

TAB LE 4 Results of the cross validation of principal co-ordinates analysis (CAP) (leave-one-out allocation of individual fish to one of six samples)

\begin{tabular}{|lcccccccc} 
Sample & MDP & ER1 & ER2 & SMG & RA1 & RA2 & Total & Correctly classified (\%) \\
\hline MDP & 47 & 3 & 1 & 0 & 0 & 0 & 51 & 92.2 \\
ER1 & 0 & 42 & 5 & 4 & 0 & 0 & 51 & 82.4 \\
\hline ER2 & 0 & 3 & 37 & 0 & 0 & 0 & 40 & 92.5 \\
SMG & 0 & 6 & 2 & 22 & 1 & 1 & 32 & 68.8 \\
\hline RA1 & 0 & 0 & 0 & 1 & 20 & 2 & 23 & 87.0 \\
\hline RA2 & 0 & 1 & 1 & 2 & 3 & 5 & 12 & 41.7 \\
\hline
\end{tabular}

Note: Rows correspond to number of fish parasite infra-communities allocated to each group, including (at far right) the percentage correctly classified in their actual sample.

Abbreviations: ER1, El Rincón 2005; ER2, El Rincón 2018; MDP, Mar del Plata; RA1, Rawson 2016; RA2, Rawson 2017; SMG, San Matías Gulf. 
TABLE 5 Results of the general linear models comparing between abundances of individual parasites from El Rincón corresponding to 2005 and 2018

\begin{tabular}{|c|c|c|c|c|c|c|}
\hline \multirow[b]{2}{*}{ Parasite species } & \multicolumn{2}{|l|}{ Year } & \multicolumn{2}{|c|}{ Size host } & \multicolumn{2}{|c|}{ Interaction (year/size host) } \\
\hline & $\chi^{2}$ & $P$ & $\chi^{2}$ & $P$ & $\chi^{2}$ & $P$ \\
\hline Corynosoma australe & 6.54 & $=0.01$ & 56.83 & $<0.01$ & 1.64 & $>0.01$ \\
\hline Corynosoma cetaceum & 5.28 & $>0.01$ & 0.30 & $>0.01$ & 1.41 & $>0.01$ \\
\hline Grillotia carvajalregorum & 69.92 & $<0.01$ & 21.13 & $<0.01$ & 5.19 & $>0.01$ \\
\hline Tentaculariidae gen. sp. & 6.09 & $>0.01$ & 0.51 & $>0.01$ & 0.00 & $>0.01$ \\
\hline Hysterothylacium sp. & 12.63 & $<0.01$ & 26.07 & $<0.01$ & 3.44 & $>0.01$ \\
\hline Anisakis simplex s.l. & 4.21 & $>0.05$ & 34.28 & $<0.01$ & 0.00 & $>0.01$ \\
\hline Pseudophyllidea plerocercoid & 11.24 & $<0.01$ & 0.74 & $>0.01$ & 0.70 & $>0.01$ \\
\hline Contracaecum sp. & 177.5 & $<0.01$ & 0.12 & $>0.01$ & 3.24 & $>0.01$ \\
\hline Moravecia argentiensis & 4.29 & $>0.01$ & 5.36 & $>0.01$ & 0.32 & $>0.01$ \\
\hline
\end{tabular}

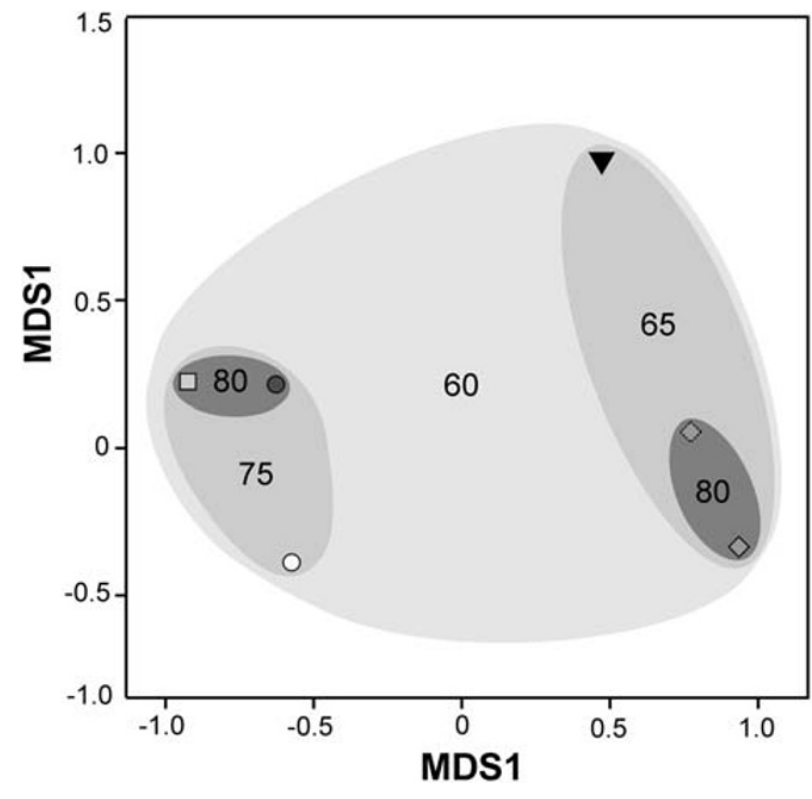

FIGURE 4 Non-metric multi-dimensional scaling plot of mean abundance (Bray-Curtis dissimilarity) of long-lived parasites in six samples of $P$. brasiliensis in the south-western Atlantic. Results of hierarchical agglomerative clustering are overlaid on the non-metric multi-dimensional scaling plot with similarity levels represented by a grey scale, with its value given as a number inside each grey area. Square, Mar del Plata; grey circle, El Rincón 1; white circle, El Rincón 2; rhombus, Rawson 1; rhombus dotted line, Rawson 2; triangle, San Matías Gulf

appropriate reforms, changes can happen quickly, with recovery of the average fishery estimated to take less than 10 years (Costello et al., 2016). Since fishing can reduce the transmission of parasites through reduction of both fish densities and food web complexity (Wood, Lafferty, \& Micheli, 2010), considerable changes in the composition of parasite assemblages are likely in increasingly fished ecosystems (Wood \& Lafferty, 2015), whose extent and direction depend on parasite life history and host fishing status (Wood \& Lafferty, 2015; Wood, Sandin, Zgliczynski, Guerra, \& Micheli, 2014). A primary effect of marine reserves is increased density of exploited populations, which facilitates parasite transmission (McCallum, Gerber, \& Jani, 2005), and a reversal of such changes in parasite burdens should therefore be expected in effectively restored fisheries.

Indeed, most previous research has recorded higher parasite species richness, diversity and abundance in protected areas (Bartoli, Gibson, \& Bray, 2005; Lafferty, Shaw, \& Kuris, 2008; Loot, Aldana, \& Navarrete, 2005; Sasal, Desdevises, Durieux, Lenfant, \& Romans, 2004; Sasal, Faliex, \& Morand, 1996; Wood et al., 2013), although other studies found no clearcut differences in assemblage structure (Ternengo, Levron, Mouillot, \& Marchand, 2009) or opposite trends of abundance across parasite species (Isbert et al., 2018; Marzoug, Boutiba, Kostadinova, \& Perez-del-Olmo, 2012). These effects on parasite communities have been used as indirect evidence on how fisheries can affect parasites (Wood \& Lafferty, 2015) in a small number of studies (Isbert et al., 2018). However, probably because all these studies were carried out by comparison between fished and protected areas, little mention has been made of the potential of parasites as indicators of the success of protected areas in recovering ecosystems (but see Isbert et al., 2018), which should include data from before and after protection measures. To the best of our knowledge, this is the first study comparing the structure of parasite communities before and after the implementation of fishery regulations in the marine environment.

As expected, results from the present study include a significant change in the structure and composition of parasite assemblages, which is a consequence of increased loads for several species. We acknowledge that, by comparing two samples, one before and the other after the implementation of protection measures, other causes of the observed variability may be overlooked. These include those related to small-scale spatial changes in parasitism, since samples were caught at different sites within the protected area, and those related to natural short- and long- term temporal oscillations or trends. However, we consider capture site and the extent of the area sampled within ER to be of little relevance as sources of variability for parasite burdens of $P$. brasiliensis. Indeed, parasite assemblages in this host are homogeneous in both composition and structure in comparisons of a single stock at much larger spatial scales (Braicovich \& Timi, 2008) and 
it is well established that a single stock of $P$. brasiliensis inhabits ER (Avigliano et al., 2015; Braicovich \& Timi, 2008; Rico et al., 2018; Rodrígues et al., 2010). Additionally, both samples from Rawson examined in the present study were separated by a similar distance as in ER but showed no differences in parasite community structure.

Temporal patterns in parasite population and community structure can be affected by environmental characteristics and host biology associated with annual or seasonal changes (Poulin, 2006). However, in this case, changes related to short-term or seasonal causes were avoided by restricting comparative analyses to larval parasites, all of them living in the body cavity or internal tissues. Members of this guild are persistent for long periods or even for the entire life of hosts (Braicovich et al., 2017; Lester \& MacKenzie, 2009; Timi \& MacKenzie, 2015), and consequently, seasonality is not expected to occur. Furthermore, both samples from ER (2005 and 2018) were caught during the same season (October), further reducing any expected influence of seasonality. Additionally, the parasite communities of $P$. brasiliensis in a neighbouring region (Braicovich \& Timi, 2010) were stable in both composition and community structure throughout the year. Indeed, other studies on temporal repeatability of community structure of the same guild (mostly the same species) of parasites in fishes from the northern Argentinean Sea have demonstrated a high degree of short-term monthly, seasonal or interannual stability (Braicovich, Luque, \& Timi, 2012; Braicovich \& Timi, 2010; Rossin \& Timi, 2010; Timi, Lanfranchi, \& Etchegoin, 2009). As a further example, both samples from Rawson, although taken during two consecutive years, were stable and showed no differences during this interval, providing further evidence of the persistence of larval parasite communities in P. brasiliensis.

Nonetheless, unmeasured variables, such as climate-driven changes in oceanography or regional changes in coastal pollution, cannot be discounted as sources of observed variability. These changes affect parasites in a variety of ways, either increasing or decreasing levels of parasitism and modifying parasite community structure, depending upon both the nature of the stressor and the group of parasites considered (Lafferty, 1997; Sures, Nachev, Selbach, \& Marcogliese, 2017). However, negative effects on parasite populations and species richness are typically observed for pollutants (Blanar, Munkittrick, Houlahan, MacLatchy, \& Marcogliese, 2009; Vidal-Martínez, Pech, Sures, Purucker, \& Poulin, 2010) and, although global warming can promote developmental rates and transmission success on a local scale, yielding higher local abundance of certain parasites (Poulin \& Mouritsen, 2006), other components of global change, such as increases in ocean acidification or ultraviolet radiation and their interactions, can result in the opposite trend (MacLeod, 2017; Studer \& Poulin, 2013), leading to decreases in parasitism (Carlson et al., 2017; Cizauskas et al., 2017). In the present study, all parasite species differing significantly in prevalence and/or abundance showed increased values of these parameters in 2018 compared with 2005. Furthermore, P. cattani and Terranova sp. were only present in samples from 2018. This pattern, which was recurrent across a variety of parasite taxa, such as cestodes, nematodes and acanthocephalans, is unlikely to result from environmental stressors, such as pollution and global change, which, as reviewed above, are expected to have mixed effects, rather than homogeneous positive effects on infection levels. Therefore, in line with previous observations of increased parasitism in marine reserves relative to exploited areas, the effect of protection measures remains as the more plausible explanation for the observed changes in parasite communities of $P$. brasiliensis in El Rincón.

Interestingly, the changes observed are unlikely to be related to an increase in the abundance or density of $P$. brasiliensis populations. An increase in host density would favour the transmission and population size of parasites specific to that host. However, M. argentinensis, the strictly specific parasite of $P$. brasiliensis, did not show changes in their population parameters in El Rincón. The other specific parasite, Cardicola ambrosioi, also living in blood vessels, showed similarly low values of prevalence and abundance in both periods. All parasites that showed increased burdens are generalist larval stages, with life-cycles involving invertebrate and vertebrate hosts. It is assumed that generalist parasites should be less susceptible than specialists to change after the implementation of protection measures (Isbert et al., 2018). However, increased loads of generalist larval parasites could reflect the restoration of ecosystem functioning via increased biodiversity and species density (Lester et al., 2009; Lubchenco, Palumbi, Gaines, \& Andelman, 2003) of both intermediate and definitive hosts. Indeed, several of the species with increased burdens in $P$. brasiliensis have elasmobranchs as definitive hosts, whose populations may have benefitted from fishing restrictions. However, since chondrichthyans are characterized by a low growth rate, high age and size at maturity, extensive period of gestation and small number of large offspring, they display very low population growth rates (Dulvy et al., 2008, 2014; Stevens, Bonfil, Dulvy, \& Walker, 2000). Unfortunately, no data on this subject are available, but given the short time since the implementation of protection measures at El Rincón zone, an increase in shark and ray populations seems less plausible as a cause of the increased parasitism observed.

Parasites of $P$. brasiliensis parasitizing marine mammals as adults, i.e. C. australe and P. cattani, both maturing in pinnipeds (Sardella et al., 2005; Timi et al., 2014), could also respond to factors not directly related to the flathead fishery. The increased burdens of these two parasites can be explained by the gradual recovery of populations of one of their definitive hosts, the sea lion, Otaria flavescens, whose resurgence took place as a consequence of the prohibition of marine mammal harvesting in Argentina in 1974, after a long period of heavy exploitation that threatened extirpation (Grandi, Dans, \& Crespo, 2015). Populations of fur seals, Arctocephalus australis, along South American coasts have also increased during recent years, probably owing to the same conservation policies (Crespo et al., 2015).

In contrast, limitations on bottom-trawl fisheries are expected to have a higher impact on the abundance of bottom invertebrate communities, with consequently strong effects on generalist larval parasites. Bottom trawling reduces benthic invertebrate abundance, biomass and diversity (Sciberras et al., 2018), selecting for communities dominated by organisms with short life-histories (Hiddink et al., 2018; van Denderen et al., 2015). However, because 
of their shorter generation times, many invertebrates are able to withstand disturbance of the seabed and display higher recovery rates (Duplisea, Jennings, Warr, \& Dinmore, 2002; Hiddink et al., 2018). The restoration of community production, trophic structure and function is therefore expected to be faster for invertebrates than for vertebrates. Since most of the parasites of $P$. brasiliensis showing changes in abundance are trophically transmitted and use crustaceans as intermediate hosts, the observed variations in El Rincón are possibly related to recovery at these lower levels of the food chain. In fact, greater transmission rates of parasites to fish owing to higher prey biomass will increase parasite population density in definitive hosts, even if their densities remain stable.

The stability of the population parameters of host-specific parasites suggests that no changes in the population size of $P$. brasiliensis took place during the study period, but the increased levels of parasites with heteroxenous life cycles can be interpreted as a sign of ecosystem recovery. Indeed, the increased prevalence of several species leads to higher species richness at the component community level, which is a characteristic of healthy ecosystems (Hudson, Dobson, \& Lafferty, 2006). On the other hand, the higher abundance and diversity of parasites in protected fish populations, owing to an increased host density that facilitates their transmission, persistence and abundance, may potentially produce negative effects on host fitness (Krkošek, 2016; McCallum et al., 2005), leading to unintended health costs for protected wildlife (Gómez \& Nichols, 2013). Conservation policies can, therefore, pose serious health risks to wildlife, whose extent depends upon the overcrowding of animals in protected areas, the size of the area and the kind of pathogen (Ezenwa, 2004; Lebarbenchon, Poulin, Gauthier-Clerc, \& Thomas, 2007). Despite the increased burdens of some helminth species observed in P. brasiliensis caught in 2018, these values are within or below the range of abundances recorded in other populations of this species throughout its distributional range (Braicovich et al., 2017). This suggests that the rate of host population increase should not be affected at the present levels of parasitism. However, given the reductions of host fitness that increases in parasitism can impose which eventually affect the recovery of host populations, changes in the transmission dynamics and their potential detrimental effects should be considered in the cost-benefit analyses of protected areas, to improve their efficacy and management strategies (Wootton et al., 2012).

Indeed, differences in parasitism in fish from exploited vs. protected areas have been used as a sign of the negative impacts of increased host densities, such as induction of unfavourable trophic cascades and disease outbreaks (Lafferty, 2004; Lebarbenchon et al., 2007; Wootton et al., 2012), exposing the need to evaluate parasitism in protected areas.

Other aspects of marine protected areas under constant evaluation are the success and performance of their different indicators (Claudet \& Guidetti, 2010; Giakoumi et al., 2018; Humphreys \& Herbert, 2018; Kockel, Ban, Costa, \& Dearden, 2020), including biological ones (Gladstone, 2002; Pelletier et al., 2005; Pelletier, Claudet, Ferraris, Benedetti-Cecchi, \& Garcìa-Charton, 2008). Parasites have proven to be suitable indicators for many aspects of the biology of their hosts, as well as sensitive indicators of changing conditions in aquatic systems (Blanar et al., 2009; Marcogliese, 2005; Sures et al., 2017). Indeed, they meet most of the the recommended criteria for suitable indicators in several branches of environmental sciences related to environmental impact analysis and evaluation of restoration processes (Bellinger \& Sigee, 2010; Gibbons, Pearthree, Cloutier, \& Ehlenz, 2020; Pander \& Geist, 2013; Roni, Hall, Drenner, \& Arterburn, 2019; Sures et al., 2017). Their value as indicators of the occurrence and magnitude of these changes relies on several characteristics of parasitism. First, parasites are ubiquitous components of ecosystems, comprise a noteworthy proportion of world biodiversity exploiting all kinds of organisms (Dobson, Lafferty, Kuris, Hechinger, \& Jetz, 2008; Poulin \& Morand, 2000) and achieving substantial biomass, abundance and productivity in some ecosystems (Kuris et al., 2008). Consequently, they are widespread and abundant in the biota, easy to identify and inexpensive to sample, especially if large host samples are being analysed. Second, by having shorter generation times, parasites can reflect changes in ecosystem conditions faster than their hosts. Third, parasites display a significant diversity of life cycles, transmission strategies and specificity, providing a battery of tools for the detection and interpretation of ongoing changes in the biology of their hosts. The replacement of the use of single biological indicators by more holistic ecological ones, simultaneously addressing communities, multiple life stages and habitat properties is often recommended (Pander \& Geist, 2013). Thus, analyses of parasite assemblages combine evidence of multiple lineages and life cycle stages, which is expected to be more efficient and robust in capturing recurrent patterns in overall biodiversity than individual taxa, especially for heteroxenous species that integrate the different chains of food webs. Fourth, since each host harbours a discrete community that can be completely recorded and quantified, parasite assemblages provide spatial and temporal replication for appropriate and robust statistical comparisons of restoration effectiveness. Finally, whereas specific parasites can provide evidence on the population parameters of their specific hosts, non-specific parasites, such as those analysed in this paper, allow corroboration, by means of analyses across host species, of any trend that can be interpreted as indicative of a restoration success from a more reliable and integrative perspective.

Marine protected areas are essential tools for reversing the global degradation of ocean life and helping to restore the complexity of ecosystems through a chain of ecological effects (Sala \& Giakoumi, 2018). Parasites, as integral components of such webs, provide, therefore, a cost-effective, reliable and robust set of bioindicators for a better and more precise monitoring of the success and effectiveness of protection measures.

Percophis brasiliensis is one of the main resources for the coastal fisheries in Argentina and its population parameters are currently monitored owing to increasing catch levels (Rico et al., 2018). However, evaluation efforts are concentrated in northern waters, north of $39^{\circ} \mathrm{S}$ (Rico et al., 2018), with no information on the status of this resource in southern regions. The significant differences between parasite assemblages observed in flatheads caught at Rawson, in 
waters belonging to the Magellanic Province, and those from lower latitudes in the Argentine Province, indicate that a discrete stock of $P$. brasiliensis inhabits the southern region. Previous studies on population parameters have determined the existence of two stocks of this species in the Argentine Sea, one in the Argentine-Uruguayan Common Fishing Zone, north of $39^{\circ} \mathrm{S}$ and a second in El Rincón (Rico et al., 2018; Rico \& Sáez, 2010; Sáez, Rico, Despós, \& Casagrande, 2011). Although flatheads from El Rincón and San Matías gulf have been considered as members of a single stock based on the chemical composition of otoliths (Avigliano et al., 2015), they have been distinguished as different on the basis of reproductive (Rodrígues et al., 2010) and parasitological evidence (Braicovich \& Timi, 2008). Consequently, this study reports the existence of a fourth stock in north Patagonian waters, whose identification provides insights into the population structure, applicable to the development of the sustainable management of this resource.

Parasites of $P$. brasiliensis have also been used as indicators of zoogeographical units in the south-west Atlantic, throughout the entire distribution of the species in the Argentine Province, from Rio de Janeiro in Brazil to San Matías Gulf in Argentina (Braicovich et al., 2017). In the northern Argentine Sea, flathead parasite assemblages are characterized by high burdens of a group of non-specific larval parasites (Braicovich et al., 2017), a pattern recurrent in all regional fish species studied, especially when compared with parasite communities in the Magellanic province (Cantatore \& Timi, 2015). The present study is the first assessment of parasite community structure in flatheads from the Magellanic Province, and shows the same trend as all previous studies. Indeed, in the present work, a significant decrease in parasite loads for typical species of the Argentine Province, such as G. carvajalregorum, C. australe, C. cetaceum and Hysterothylacium sp. was observed in both samples from Rawson, whereas the opposite trend was evident for the anisakids Anisakis simplex s.l., P. cattani, H. aduncum and Contracaecum sp., which are commonly found at higher loads in the colder north Patagonian waters of the Magellanic Province (Cantatore \& Timi, 2015; Lanfranchi et al., 2018; Timi et al., 2014).

Spatial variability of fish parasites has been largely used as a tool for stock assessment and, to lesser extent, for biogeographical purposes or for evaluating the effect of fisheries on marine resources. Although temporal varibility in parasite burdens has been successfully used to understand a variety of environmental problems (Sures et al., 2017), it has received less attention from a fisheries perspective. The observed changes in parasite assemblages of $P$. brasiliensis after the implementation of protection measures reveal that their responsiveness to anthropogenic disturbances might be advantageous not only to detect environmental problems, but also for monitoring the success of protection measurements implemented to promote the recovery of the resources.

\section{ACKNOWLEDGEMENTS}

We are grateful to Dr Sean Locke (Department of Biology, University of Puerto Rico, Mayagüez) for his helpful comments on the manuscript. Thanks are extended to the Instituto Nacional de
Investigación y Desarrollo Pesquero, especially to Drs C. Ruarte, R. Rico and C. Carozza for providing fish samples from El Rincón. Financial support was provided by grants from Consejo Nacional de Investigaciones Científicas y Técnicas (PIP no. 112-201501-00973); Fondo para la Investigación Científica y Tecnológica (PICT 2015 no. 2018-01981) and Universidad Nacional de Mar del Plata (EXA 1016/20).

\section{CONFLICT OF INTEREST}

The authors have no conflicts of interest to declare.

\section{ORCID}

Paola E. Braicovich (D) https://orcid.org/0000-0002-2501-3452

Manuel M. Irigoitia (D) https://orcid.org/0000-0003-2193-6775

Nelson D. Bovcon (1D) https://orcid.org/0000-0002-3786-406X

Juan T. Timi (D) https://orcid.org/0000-0003-3717-0030

\section{REFERENCES}

Acha, E. M., Mianzán, H. W., Guerrero, R. A., Favero, M., \& Bava, J. (2004). Marine fronts at the continental shelves of austral South America physical and ecological process. Journal of Marine Systems, 44, 83-105. https://doi.org/10.1016/j.jmarsys.2003.09.005

Acha, E. M., Orduna, M., Rodrigues, K., Militelli, M. I., \& Braverman, M. (2012). Caracterización de la zona de 'El Rincón' (Provincia de Buenos Aires) como área de reproducción de peces costeros. Revista de Investigación Y Desarrollo Pesquero, 21, 31-43. http://hdl.handle.net/ $1834 / 4910$

Anderson, M. J., Gorley, R. N., \& Clarke, K. R. (2008). PERMANOVA+ for PRIMER: Guide to software and statistical methods. Plymouth: PRIMERE. https://doi.org/10.1016/j.hal.2008.08.017

Anderson, M. J., \& Robinson, J. (2003). Generalized discriminant analysis based on distances. Australian \& New Zealand Journal of Statistics, 45, 301-318. https://doi.org/10.1111/1467-842X.00285

Anderson, M. J., \& Willis, T. J. (2003). Canonical analysis of principal coordinates: A useful method of constrained ordination for ecology. Ecology, 84, 511-525. https://doi.org/10.1890/0012-9658(2003)084 [0511:CAOPCA]2.0.CO;2

Avigliano, E., Sáez, M. B., Rico, M. R., \& Volpedo, A. (2015). Use of otolith strontium: Calcium and zinc: Calcium ratios as an indicator of the habitat of Percophis brasiliensis Quoy \& Gaimard, 1825 in the southwestern Atlantic Ocean. Neotropical Ichthyology, 13, 187-194. https://doi.org/10.1590/1982-0224-20130235

Balech, E., \& Ehrlich, M. D. (2008). Esquema biogeográfico del Mar Argentino. Revista de Investigación Y Desarrollo Pesquero, 19, 45-75.

Barretto, A. C., Sáez, M. B., Rico, M. R., \& Jaureguizar, A. J. (2011). Age determination, validation, and growth of Brazilian flathead (Percophis brasiliensis) from the southwest Atlantic coastal waters $\left(34^{\circ}-41^{\circ} \mathrm{S}\right)$. Latin American Journal of Aquatic Research, 39, 297-305. https://doi. org/10.3856/vol39-issue2-fulltext-11

Bartoli, P., Gibson, D. I., \& Bray, R. A. (2005). Digenean species diversity in teleost fish from a nature reserve off Corsica, France (Western Mediterranean) and a comparison with other Mediterranean regions. Journal of Natural History, 39, 47-70. https://doi.org/10.1080/ 00222930310001613557

Bellinger, E. G., \& Sigee, D. C. (2010). Freshwater algae: Identification and use as bioindicators. Chichester: John Wiley \& Sons. https://doi.org/ 10.1002/9780470689554

Blanar, C. A., Munkittrick, K. R., Houlahan, J., MacLatchy, D. L., \& Marcogliese, D. J. (2009). Pollution and parasitism in aquatic animals: A meta-analysis of effect size. Aquatic Toxicology, 93, 18-28. https:// doi.org/10.1016/j.aquatox.2009.03.002 
Braicovich, P. E., Luque, J. L., \& Timi, J. T. (2012). Geographical patterns of parasite infracommunities in the rough scad, Trachurus lathami Nichols, in the southwestern Atlantic ocean. Journal of Parasitology, 98, 768-777. https://doi.org/10.1645/GE-2950.1

Braicovich, P. E., Pantoja, C., Pereira, A. N., Luque, J. L., \& Timi, J. T. (2017). Parasites of the Brazilian flathead Percophis brasiliensis reflect West Atlantic biogeographic regions. Parasitology, 144, 169-178. https:// doi.org/10.1017/S0031182016001050

Braicovich, P. E., \& Timi, J. T. (2008). Parasites as biological tags for stock discrimination of the Brazilian flathead, Percophis brasiliensis in the south-west Atlantic. Journal of Fish Biology, 73, 557-571. https://doi. org/10.1111/j.1095-8649.2008.01948.x

Braicovich, P. E., \& Timi, J. T. (2010). Seasonal stability in parasite assemblages of the Brazilian flathead, Percophis brasiliensis (Perciformes: Percophidae): Predictable tools for stock identification. Folia Parasitologica, 57, 206-212. https://doi.org/10.14411/fp. 2010.027

Bush, A. O., Aho, J. M., \& Kennedy, C. R. (1990). Ecological versus phylogenetic determinants of helminth parasite commnity richness. Evolutionary Ecology, 4, 1-20. https://doi.org/10.1007/BF02270711

Bush, A. O., Lafferty, K. D., Lotz, J. M., \& Shostak, A. W. (1997). Parasitology meets ecology on its own terms: Margolis et al. Revisited. Journal of Parasitology, 83, 575-583. https://doi.org/10.2307/3284227

Cantatore, D. M. P., \& Timi, J. T. (2015). Marine parasites as biological tags in South American Atlantic waters, current status and perspectives. Parasitology, 142, 5-24. https://doi.org/10.1017/ S0031182013002138

Carlson, C. J., Burgio, K. R., Dougherty, E. R., Phillips, A. J., Bueno, V. M., Clements, C. F., ... Getz, W. M. (2017). Parasite biodiversity faces extinction and redistribution in a changing climate. Science Advances, 3, e1602422. https://doi.org/10.1126/sciadv.1602422

Carozza, C., Fernandez Aráoz, N., Ruarte, C., Massa, A., Hozbor, N., \& Jaureguizar, A. (2004). Definición de una zona de reproducción y cría de especies demersales costeras en la costa sur de la provincia de Buenos Aires. Informe Técnico Interno INIDEP, 84, 1-24.

Cizauskas, C. A., Carlson, C. J., Burgio, K. R., Clements, C. F., Dougherty, E. R., Harris, N. C., \& Phillips, A. J. (2017). Parasite vulnerability to climate change: An evidence-based functional trait approach. Royal Society Open Science, 4, 160535. https://doi.org/ 10.1098/rsos.160535

Clarke, K. R., \& Gorley, R. N. (2015). PRIMER v7: User manual/tutorial. Plymouth: PRIMER-E Ltd.

Claudet, J., \& Guidetti, P. (2010). Improving assessments of marine protected areas. Aquatic Conservation: Marine and Freshwater Ecosystems, 20, 239-242. https://doi.org/10.1002/aqc.1087

Costello, C., Ovando, D., Clavelle, T., Strauss, C. K., Hilborn, R., Melnychuk, M. C., ... Leland, A. (2016). Global fishery prospects under contrasting management regimes. Proceedings of the National Academy of Sciences of the United States of America, 113, 5125-5129. https:// doi.org/10.1073/pnas.1520420113

Cousseau, M. B., \& Perrotta, R. G. (2013). Peces marinos de Argentina: Biología, distribución, pesca (4th ed.) (p. 193). Mar del Plata: Instituto Nacional de Investigación y Desarrollo Pesquero.

Crespo, E. A., Schiavini, A. C. M., García, N. A., Franco-Trecu, V., Goodall, R. N. P., Rodríguez, D., ... de Oliveira, L. R. (2015). Status, population trend and genetic structure of South American fur seals, Arctocephalus australis, in southwestern Atlantic waters. Marine Mammal Science, 31, 866-890. https://doi.org/10.1111/mms.12199

de Bruyn, P., Murua, H., \& Aranda, M. (2013). The precautionary approach to fisheries management: How this is taken into account by tuna regional fisheries management organisations (RFMOs). Marine Policy, 38, 397-406. https://doi.org/10.1016/j.marpol.2012.06.019

Dobson, A., Lafferty, K. D., Kuris, A. M., Hechinger, R. F., \& Jetz, W. (2008). Homage to Linnaeus: How many parasites? How many hosts? Proceedings of the National Academy of Sciences of the United States of America, 105, 11482-11489. https://doi.org/10.1073/pnas. 0803232105

Dulvy, N. K., Baum, J. K., Clarke, S., Compagno, L. J. V., Cortes, E., Domingo, A., ... Valenti, S. (2008). You can swim but you can't hide: The global status and conservation of oceanic pelagic sharks and rays. Aquatic Conservation: Marine and Freshwater Ecosystems, 18, 459-482. https://doi.org/10.1002/aqc.975

Dulvy, N. K., Fowler, S. L., Musick, J. A., Cavanagh, R. D., Kyne, P. M., Harrison, L. R., ... White, W. T. (2014). Extinction risk and conservation of the world's sharks and rays. eLife, 3, e00590. https://doi.org/ 10.7554/eLife.00590

Duplisea, D. E., Jennings, S., Warr, K. J., \& Dinmore, T. A. (2002). A size-based model of the impacts of bottom trawling on benthic community structure. Canadian Journal of Fisheries and Aquatic Sciences, 59, 1785-1795. https://doi.org/10.1139/f02-148

Edgar, G. J., Stuart-Smith, R. D., Willis, T. J., Kininmonth, S., Baker, S. C., Banks, S., ... Thomson, R. (2014). Global conservation outcomes depend on marine protected areas with five key features. Nature, 506, 216-220. https://doi.org/10.1038/nature13022

Ezenwa, V. O. (2004). Host social behavior and parasitic infection: A multifactorial approach. Behavioral Ecology, 15, 446-454. https://doi. org/10.1093/beheco/arh028

Fernández Aráoz, N. C., Lagos, A. N., \& Carozza, C. R. (2014). Asociación íctica costera bonaerense 'Variado Costero' - Capturas declaradas por la flota comercial argentina durante el año 2013. Informe Técnico Oficial $\mathrm{N}^{\circ} 11$ INIDEP.

Fox, J., Weisberg, S., Adler, D., Bates, D., Baud-Bovy, G., Ellison, S., ... Monette, G. (2016). Companion to Applied Regression. Cran R, 622.

Gell, F. R., \& Roberts, C. M. (2002). The fishery effects of marine reserves and fishery closures. Washington, DC: WWF-US. https://doi.org/ 10.1016/s1386-5056(02)00038-2

Giakoumi, S., McGowan, J., Mills, M., Beger, M., Bustamante, R. H., Charles, A., ... Possingham, H. P. (2018). Revisiting 'success' and 'failure' of marine protected areas: A conservation scientist perspective. Frontiers in Marine Science, 5, 223. https://doi.org/10.3389/fmars. 2018.00223

Gibbons, L. V., Pearthree, G., Cloutier, S. A., \& Ehlenz, M. M. (2020). The development, application, and refinement of a regenerative development evaluation tool and indicators. Ecological Indicators, 108, 105698. https://doi.org/10.1016/j.ecolind.2019.105698

Gladstone, W. (2002). The potential value of indicator groups in the selection of marine reserves. Biological Conservation, 104, 211-220. https://doi.org/10.1016/S0006-3207(01)00167-7

Gómez, A., \& Nichols, E. (2013). Neglected wild life: Parasitic biodiversity as a conservation target. International Journal for Parasitology: Parasites and Wildlife, 2, 222-227. https://doi.org/10.1016/j.jippaw.2013.07.002

Grandi, M. F., Dans, S. L., \& Crespo, E. A. (2015). The recovery process of a population is not always the same: The case of Otaria flavescens. Marine Biology Research, 11, 225-235. https://doi.org/10.1080/ 17451000.2014.932912

Halpern, B. S. (2003). The impact of marine reserves: Do reserves work and does reserve size matter? Ecological Applications, 13 117-137. https://doi.org/10.1890/1051-0761(2003)013[0117: TIOMRD]2.0.CO;2

Hiddink, J. G., Jennings, S., Sciberras, M., Bolam, S. G., Cambiè, G., McConnaughey, R. A., ... Parma, A. M. (2018). Assessing bottomtrawling impacts based on the longevity of benthic invertebrates. Journal of Applied Ecology, 56, 1075-1084. https://doi.org/10.1002/ 9780470689554

Hudson, P. J., Dobson, A. P., \& Lafferty, K. D. (2006). Is a healthy ecosystem one that is rich in parasites? Trends in Ecology \& Evolution, 21, 381-385. https://doi.org/10.1016/j.tree.2006.04.007

Humphreys, J., \& Herbert, R. J. (2018). Marine protected areas: Science, policy \& management. Estuarine, Coastal and Shelf Science, 215, 215-218. https://doi.org/10.1016/j.ecss.2018.10.014 
Isbert, W., Montero, F. E., Pérez-del-Olmo, A., López-Sanz, A., Reñones, O., \& Orejas, C. (2018). Parasite communities of the white seabream Diplodus sargus sargus in the marine protected area of Medes Islands, northwest Mediterranean Sea. Journal of Fish Biology, 93, 586-596. https://doi.org/10.1111/jfb.13729

Kockel, A., Ban, N. C., Costa, M., \& Dearden, P. (2020). Evaluating approaches for scaling-up community-based marine-protected areas into socially equitable and ecologically representative networks. Conservation Biology, 34, 137-147. https://doi.org/10.1111/cobi.13368

Krkošek, M. (2016). Population biology of infectious diseases shared by wild and farmed fish. Canadian Journal of Fisheries and Aquatic Sciences, 74, 620-628. https://doi.org/10.1139/cjfas-2016-0379

Kuris, A. M., Hechinger, R. F., Shaw, J. C., Whitney, K., Aguirre-Macedo, L., Boch, C., ... Laffert, K. D. (2008). Ecosystem energetic implications of parasite and free-living biomass in three estuaries. Nature, 454, 515-518. https://doi.org/10.1038/nature06970

Lafferty, K. D. (1997). Environmental Parasitology: What can parasites tell us about human impacts on the environment? Parasitolology Today, 13, 251-255. https://doi.org/10.1016/S0169-4758(97)01072-7

Lafferty, K. D. (2004). Fishing for lobsters indirectly increases epidemics in sea urchins. Ecological Applications, 14, 1566-1573. https://doi.org/ 10.1890/03-5088

Lafferty, K. D., Shaw, J. C., \& Kuris, A. M. (2008). Reef fishes have higher parasite richness at unfished Palmyra Atoll compared to fished Kiritimati Island. EcoHealth, 5, 338-345. https://doi.org/10.1007/ s10393-008-0196-7

Lanfranchi, A. L., Braicovich, P. E., Cantatore, D. M. P., Alarcos, A. J., Luque, J. L., \& Timi, J. T. (2016). Ecotonal marine regions - Ecotonal parasite communities: Helminth assemblages in the convergence of masses of water in the southwestern Atlantic Ocean. International Journal for Parasitology, 46, 809-818. https://doi.org/10.1016/j.ijpara. 2016.07.004

Lanfranchi, A. L., Braicovich, P. E., Cantatore, D. M. P., Irigoitia, M. M., Farber, M. D., Taglioretti, V., \& Timi, J. T. (2018). Influence of confluent marine currents in an ecotonal region of the South-West Atlantic on the distribution of larval anisakids (Nematoda: Anisakidae). Parasites \& Vectors, 11, 1-13. https://doi.org/10.1186/s13071-0183119-7

Lebarbenchon, C., Poulin, R., Gauthier-Clerc, M., \& Thomas, F. (2007). Parasitological consequences of overcrowding in protected areas. EcoHealth, 3, 303-307. https://doi.org/10.1007/s10393-006-0067-z

Lester, R. J. G., \& MacKenzie, K. (2009). The use and abuse of parasites as stock markers for fish. Fisheries Research, 97, 1-2. https://doi.org/ 10.1016/j.fishres.2008.12.016

Lester, S. E., Halpern, B. S., Grorud-Colvert, K., Lubchenco, J., Ruttenberg, B. I., Gaines, S. D., ... Warner, R. R. (2009). Biological effects within no-take marine reserves: A global synthesis. Marine Ecology Progress Series, 384, 33-46. https://doi.org/10.3354/ meps08029

Loot, G., Aldana, M., \& Navarrete, S. A. (2005). Effects of human exclusión on parasitism in intertidal food webs of Central Chile. Conservation Biology, 19, 203-212. https://doi.org/10.1111/j.1523-1739.2005. 00396.x

Lubchenco, J., Palumbi, S. R., Gaines, S. D., \& Andelman, S. (2003). Plugging the hole in the ocean: The emerging science of marine reserves. Ecological Applications, 13, S3-S7. https://doi.org/10.1890/ 1051-0761(2003)013[0003:pahito]2.0.co;2

MacLeod, C. D. (2017). Parasitic infection: A missing piece of the ocean acidification puzzle. ICES Journal of Marine Science, 74, 929-933. https://doi.org/10.1093/icesjms/fsw156

Marcogliese, D. (2005). Parasites of the superorganism: Are they indicators of ecosystem health? International Journal for Parasitology, 35, 705-716. https://doi.org/10.1016/j.ijpara.2005.01.015

Marzoug, D., Boutiba, Z., Kostadinova, A., \& Perez-del-Olmo, A. (2012). Effects of fishing on parasitism in a sparid fish: Contrasts between two areas of the western Mediterranean. Parasitology International, 61, 414-420. https://doi.org/10.1016/j.parint.2012.02.002

McCallum, H., Gerber, L., \& Jani, A. (2005). Does infectious disease influence the efficacy of marine protected areas? A theoretical framework. Journal of Applied Ecology, 42, 688-698. https://doi.org/ 10.1111/j.1365-2664.2005.01043.x

Menni, R. C., Jaureguizar, A. J., Stehmann, M. F., \& Lucifora, L. O. (2010). Marine biodiversity at the community level: Zoogeography of sharks, skates, rays and chimaeras in the southwestern Atlantic. Biodiversity and Conservation, 19, 775-796. https://doi.org/10.1007/s10531-0099734-z

Miloslavich, P., Klein, E., Díaz, J. M., Hernandez, C. E., Bigatti, G., Campos, L., ... Martin, A. (2011). Marine biodiversity in the Atlantic and Pacific coasts of South America: Knowledge and gaps. PLoS ONE, 6, e14631. https://doi.org/10.1371/journal.pone.0014631

Mullon, C., Fréon, P., \& Cury, P. (2005). The dynamics of collapse in world fisheries. Fish and Fisheries, 6, 111-120. https://doi.org/10.1111/j. 1467-2979.2005.00181.x

Pander, J., \& Geist, J. (2013). Ecological indicators for stream restoration success. Ecological Indicators, 30, 106-118. https://doi.org/10.1016/j. ecolind.2013.01.039

Pauly, D., Christensen, V., Dalsgaard, J., Froese, R., \& Torres, F. (1998). Fishing down marine foods webs. Science, 279, 860-863. https://doi. org/10.1126/science.279.5352.860

Pelletier, D., Claudet, J., Ferraris, J., Benedetti-Cecchi, L., \& Garcia-Charton, J. A. (2008). Models and indicators for assessing conservation and fisheries-related effects of marine protected areas. Canadian Journal of Fisheries and Aquatic Sciences, 65, 765-779. https://doi.org/10.1139/f08-026

Pelletier, D., García-Charton, J. A., Ferraris, J., David, G., Thébaud, O., Letourneur, Y., ... Galzin, R. (2005). Designing indicators for assessing the effects of marine protected areas on coral reef ecosystems: A multidisciplinary standpoint. Aquatic Living Resources, 18, 15-33. https://doi.org/10.1051/alr:2005011

Pikitch, E. K. (2012). The risks of overfishing. Science, 338, 474-475. https://doi.org/10.1126/science.1229965

Poulin, R. (2006). Variation in infection parameters among populations within parasite species: Intrinsic properties versus local factors. International Journal for Parasitology, 36, 877-885. https://doi.org/ 10.1016/j.ijpara.2006.02.021

Poulin, R., \& Morand, S. (2000). The diversity of parasites. The Quarterly Review of Biology, 75, 277-293. https://doi.org/10.1086/393500

Poulin, R., \& Mouritsen, K. N. (2006). Climate change, parasitism and the structure of intertidal ecosystems. Journal of Helminthology, 80, 183-191. https://doi.org/10.1079/JOH2006341

Rico, M. R., Lagos, A. N., Rodríguez, J. S., \& Lorenzo, M. I. (2018). Estado de la pesquería de pez palo (Percophis brasiliensis) en el área del Río de la Plata, Zona Común de Pesca Argentino-Uruguaya y aguas jurisdiccionales adyacentes al norte de los $39^{\circ} \mathrm{S}$. Frente Maritimo, 25, 117-146.

Rico, M. R., \& Sáez, M. B. (2010). Análisis de la estructura de tallas; determinación de la edad, validación y crecimiento de pez palo (Percophis brasiliensis) a partir de muestras del desembarque comercial en el puerto de Mar del Plata. Informe de Investigación INIDEP, $85,1-20$.

Ripley, B., Venables, B., Bates, D. M., Hornik, K., Gebhardt, A., \& Firth, D. (2019). MASS: Support Functions and Datasets for Venables and Ripley's MASS. Cran R, 3496. https://CRAN.R-project.org/package= MASS

Roberts, C. M., Hawkins, J. P., \& Gelly, F. R. (2005). The role of marine reserves in achieving sustainable fisheries. Philosophical Transactions of the Royal Society, B: Biological Sciences, 360, 123-132. https://doi.org/ 10.1098/rstb.2004.1578

Rodrígues, K. A., Rico, M. R., Militelli, M. I., Osovnikar, P., \& Maggioni, M. (2010). Parámetros reproductivos y distribución de las hembras de pez 
palo (Percophis brasiliensis) y lenguado (Paralichthys patagonicus) en el Golfo San Matías. Informe de Investigación INIDEP, 65, 1-20.

Roni, P., Hall, J. E., Drenner, S. M., \& Arterburn, D. (2019). Monitoring the effectiveness of floodplain habitat restoration: A review of methods and recommendations for future monitoring. Wiley Interdisciplinary Reviews Water, 6, e1355. https://doi.org/10.1002/wat2.1355

Rossin, M. A., \& Timi, J. T. (2010). Parasite assemblages of Nemadactylus bergi (Pisces: Latridae): The role of larval stages in the short-scale predictability. Parasitology Research, 107, 1373-1379. https://doi.org/ 10.1007/s00436-010-2011-y

Ruarte, C., Rico, M. R., \& Lagos, A. N. (2017). Estimación de los índices de abundancia de peces óseos a partir de datos de campañas de

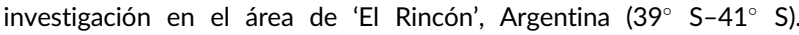
Período 1994-2012. Informe Técnico INIDEP, 98, 1-45.

Sáez, M. B., Rico, M. R., Despós, J., \& Casagrande, P. (2011). Análisis de la estructura de tallas; determinación de la edad y crecimiento de pez palo (Percophis brasiliensis) a partir de muestras del desembarque comercial durante el año 2008 en el puerto de Mar del Plata. Informe de Investigación INIDEP, 97, 1-17.

Sala, E., \& Giakoumi, S. (2018). No-take marine reserves are the most effective protected areas in the ocean. ICES Journal of Marine Science, 75, 1166-1168. https://doi.org/10.1093/icesjms/fsx059

Sardella, N. H., Mattiucci, S., Timi, J. T., Bastida, R., Rodríguez, D., \& Nascetti, G. (2005). Corynosoma australe Johnston, 1937 and C. cetaceum Johnston and Best, 1942 (Acanthocephala: Polymorphidae) from marine mammals and fish in Argentinean waters: Genetic differentiation and taxonomic status. Systematic Parasitology, 61, 143-156. https://doi.org/ 10.1007/s11230-005-3131-0

Sasal, P., Desdevises, Y., Durieux, E., Lenfant, P., \& Romans, P. (2004). Parasites in marine protected areas: Success and specificity of monogeneans. Journal of Fish Biology, 64, 370-379. https://doi.org/ 10.1111/j.0022-1112.2004.00297.x

Sasal, P., Faliex, E., \& Morand, S. (1996). Parasitism of Gobius bucchichii Steindachner 1870 (Teleostei, Gobiidae) in protected and unprotected marine environments. Journal of Wildlife Diseases, 32, 607-613. https://doi.org/10.7589/0090-3558-32.4.607

Sciberras, M., Hiddink, J. G., Jennings, S., Szostek, C. L., Hughes, K. M., Kneafsey, B., ... Kaiser, M. J. (2018). Response of benthic fauna to experimental bottom fishing: A global meta-analysis. Fish and Fisheries, 19, 698-715. https://doi.org/10.1111/faf.12283

Stevens, J. D., Bonfil, R., Dulvy, N. K., \& Walker, P. A. (2000). The effects of fishing on sharks, rays, and chimaeras (chondrichthyans), and the implications for marine ecosystems. ICES Journal of Marine Science, 57, 476-494. https://doi.org/10.1006/jmsc.2000.0724

Studer, A., \& Poulin, R. (2013). Cercarial survival in an intertidal trematode: A multifactorial experiment with temperature, salinity and ultraviolet radiation. Parasitology Research, 112, 243-249. https://doi.org/ 10.1007/s00436-012-3131-3

Sures, B., Nachev, M., Selbach, C., \& Marcogliese, D. J. (2017). Parasite responses to pollution: What we know and where we go in 'Environmental Parasitology'. Parasites \& Vectors, 10, 65. https://doi. org/10.1186/s13071-017-2001-3

Ternengo, S., Levron, C., Mouillot, D., \& Marchand, B. (2009). Site influence in parasite distribution from fishes of the Bonifacio Strait Marine Reserve (Corsica Island, Mediterranean Sea). Parasitology Research, 104, 1279-1287. https://doi.org/10.1007/s00436-008-1323-7

Timi, J. T., Lanfranchi, A. L., \& Etchegoin, J. A. (2009). Seasonal stability and spatial variability of parasites in Brazilian sandperch Pinguipes brasilianus from the Northern Argentine Sea: Evidence for stock discrimination. Journal of Fish Biology, 74, 1206-1225. https://doi.org/ 10.1111/j.1095-8649.2009.02190.x
Timi, J. T., \& MacKenzie, K. (2015). Parasites in fisheries and mariculture. Parasitology, 142, 1-4. https://doi.org/10.1017/S0031182014001188

Timi, J. T., Paoletti, M., Cimmaruta, R., Lanfranchi, A. L., Alarcos, A. J., Garbin, L., ... Mattiucci, S. (2014). Molecular identification, morphological characterization and new insights into the ecology of larval Pseudoterranova cattani in fishes from the Argentine coast with its differentiation from the Antarctic species, P. decipiens sp. E (Nematoda: Anisakidae). Veterinary Parasitology, 199, 59-72. https://doi.org/10.1016/j.vetpar.2013.09.033

van Denderen, P. D., Bolam, S. G., Hiddink, J. G., Jennings, S., Kenny, A., Rijnsdorp, A. D., \& van Kooten, T. (2015). Similar effects of bottom trawling and natural disturbance on composition and function of benthic communities across habitats. Marine Ecology Progress Series, 541 , 31-43. https://doi.org/10.3354/meps11550

van Gemert, R., \& Andersen, K. H. (2018). Challenges to fisheries advice and management due to stock recovery. ICES Journal of Marine Science, 75, 1864-1870. https://doi.org/10.1093/icesjms/fsy084

Vidal-Martínez, V. M., Pech, D., Sures, B., Purucker, T., \& Poulin, R. (2010). Can parasites really reveal environmental impact? Trends in Parasitology, 26, 44-51. https://doi.org/10.1016/j.pt.2009.11.001

Watson, R., Cheung, W. W. L., Anticamara, J., Sumaila, R. U., Zeller, D., \& Pauly, D. (2013). Global marine yield halved as fishing intensity redoubles. Fish and Fisheries, 14, 493-503. https://doi.org/10.1111/ j.1467-2979.2012.00483.x

Wood, C. L., \& Lafferty, K. D. (2015). How have fisheries affected parasite communities? Parasitology, 142, 134-144. https://doi.org/10.1017/ S003118201400002X

Wood, C. L., Lafferty, K. D., \& Micheli, F. (2010). Fishing out marine parasites? Impacts of fishing on rates of parasitism in the ocean. Ecology Letters, 13, 761-775. https://doi.org/10.1111/j.1461-0248. 2010.01467.x

Wood, C. L., Micheli, F., Fernández, M., Gelcich, S., Castilla, J. C., \& Carvajal, J. (2013). Marine protected areas facilitate parasite populations among four fished host species of Central Chile. Journal of Animal Ecology, 82, 1276-1287. https://doi.org/10.1111/1365-2656. 12104

Wood, C. L., Sandin, S. A., Zgliczynski, B., Guerra, A. S., \& Micheli, F. (2014). Fishing drives declines in fish parasite diversity and has variable effects on parasite abundance. Ecology, 95, 1929-1946. https://doi.org/10.1890/13-1270.1

Wootton, E. C., Woolmer, A. P., Vogan, C. L., Pope, E. C., Hamilton, K. M., \& Rowley, A. F. (2012). Increased disease calls for a cost-benefits review of marine reserves. PLoS ONE, 7, e51615. https://doi.org/10.1371/journal.pone.0051615

Zar, J. H. (1999). Biostatistical analysis (4th ed.). Upper Saddle River, NJ: Prentice Hall. https://doi.org/10.1080/02724939992581

Zuur, A., leno, E. N., Walker, N., Saveliev, A. A., \& Smith, G. M. (2009). Mixed effects models and extensions in ecology with R. New York: Springer Science \& Business Media. DOI: href="https://doi.org/10. 1007/978-0-387-87458-6

How to cite this article: Braicovich PE, Irigoitia MM, Bovcon ND, Timi JT. Parasites of Percophis brasiliensis (Percophidae) benefited from fishery regulations: Indicators of success for marine protected areas? Aquatic Conserv: Mar Freshw Ecosyst. 2020;1-14. https://doi.org/10.1002/aqc.3436 